\title{
Physical disabilities caused by leprosy in 100 million cohort in Brazil
}

\author{
Mauro Niskier Sanchez ${ }^{1,2^{*}+}$ (D) Joilda Silva Nery ${ }^{3 \dagger}$, Júlia Moreira Pescarini ${ }^{2}$, André Alves Mendes ${ }^{2,4}$, \\ Maria Yury Ichihara ${ }^{2}$, Camila Silveira Silva Teixeira ${ }^{2,3}$, Maria Lúcia Fernandes Penna ${ }^{5}$, Liam Smeeth ${ }^{6,7}$, \\ Laura Cunha Rodrigues ${ }^{8}$, Maurício Lima Barreto ${ }^{2 \dagger}$, Elizabeth B. Brickley ${ }^{8+}$ and Gerson Oliveira Penna ${ }^{1,9+}$
}

\begin{abstract}
Background: Leprosy continues to be an important cause of physical disability in endemic countries such as Brazil. Knowledge of determinants of these events may lead to better control measures and targeted interventions to mitigate its impact on affected individuals. This study investigated such factors among the most vulnerable portion of the Brazilian population.

Methods: A large cohort was built from secondary data originated from a national registry of applicants to social benefit programs, covering the period 2001-2015, including over 114 million individuals. Data were linked to the leprosy notification system utilizing data from 2007 until 2014. Descriptive and bivariate analyses lead to a multivariate analysis using a multinomial logistic regression model with cluster-robust standard errors. Associations were reported as Odds Ratios with their respective 95\% confidence intervals.

Results: Among the original cohort members 21,565 new leprosy cases were identified between 2007 and 2014. Most of the cases (63.1\%) had grade zero disability. Grades 1 and 2 represented 21 and 6\%, respectively. Factors associated with increasing odds of grades 1 and 2 disability were age over 15 years old (ORs 2.39 and 1.95, respectively), less schooling (with a clear dose response effect) and being a multibacillary patient (ORs 3.5 and 8.22). Protective factors for both grades were being female (ORs 0.81 and 0.61 ) and living in a high incidence municipality (ORs 0.85 and 0.67).

\footnotetext{
* Correspondence: mauro.sanchez4@gmail.com

${ }^{\dagger}$ Mauro Niskier Sanchez and Joilda Silva Nery denotes equal contribution of the first authors.

${ }^{+}$Maurício Lima Barreto, Elizabeth B. Brickley and Gerson Oliveira Penna denotes equal contribution of the senior authors.

${ }^{1}$ Núcleo de Medicina Tropical, Universidade de Brasília, Avenida L3 Norte, s/ $n^{\circ}$, Campus Universitário Darcy Ribeiro, Gleba A, Brasília, Distrito Federal CEP 70297-400, Brazil

${ }^{2}$ Centro de Integração de Dados e Conhecimentos para Saúde (Cidacs), Fundação Oswaldo Cruz, Rua Mundo, s/nº Parque Tecnológico da Bahia Trobogy, Salvador CEP 41745-715, Brazil

Full list of author information is available at the end of the article
}

C The Author(s). 2021 Open Access This article is licensed under a Creative Commons Attribution 4.0 International License, which permits use, sharing, adaptation, distribution and reproduction in any medium or format, as long as you give appropriate credit to the original author(s) and the source, provide a link to the Creative Commons licence, and indicate if changes were made. The images or other third party material in this article are included in the article's Creative Commons licence, unless indicated otherwise in a credit line to the material. If material is not included in the article's Creative Commons licence and your intended use is not permitted by statutory regulation or exceeds the permitted use, you will need to obtain permission directly from the copyright holder. To view a copy of this licence, visit http://creativecommons.org/licenses/by/4.0/ The Creative Commons Public Domain Dedication waiver (http://creativecommons.org/publicdomain/zero/1.0/) applies to the data made available in this article, unless otherwise stated in a credit line to the data. 


\begin{abstract}
(Continued from previous page)
Conclusions: The findings suggest that the developing of physical disabilities remains a public health problem which increases the burden of leprosy, mainly for those with severe clinical features and worse socioeconomic conditions. Early diagnosis is paramount to decrease the incidence of leprosy-related disability and our study points to the need for strengthening control actions in non-endemic areas in Brazil, where cases may be missed when presented at early stages in disease. Both actions are needed, to benefit patients and to achieve the WHO goal in reducing physical disabilities among new cases of leprosy.
\end{abstract}

Keywords: Physical disabilities, Leprosy, Socioeconomic factor, Brazil

\section{Background}

Chronic infections with Mycobacterium leprae have the potential to cause lasting nerve damage and physical disabilities $[1,2]$. Among patients with leprosy, physical disabilities arise as a result of late diagnosis and/or insufficient treatments. The incidence of leprosy-related disabilities among newly detected cases is, therefore, an important indicator of gaps in population-level leprosy control strategies. Leprosy cases are classified as: Grade 0 disability (GOD), when muscle strength and sensitivity of these segments are preserved; Grade 1 (G1D), when there are decreased muscle strength and/or decreased sensitivity; and Grade 2 (G2D), when there are visible deformities in the hands, feet, and/or eyes $[3,4]$.

As part of the 2016-2020 Global Leprosy Strategy, the World Health Organization (WHO) has set a target of reducing the rate of newly diagnosed leprosy patients with G2D to less than 1 per million population [4]. In Brazil, a country with a high leprosy new case detection rate $(13.7 / 100,000$ population in 2018), the National Leprosy Disease Program has similarly prioritized reducing the rate of diagnosis with G2D as a primary goal. From 2012 to 2016, the mean rate of leprosy new case detection with G2D in Brazil was 10.5 per 1 million inhabitants, with an average of 2042 people diagnosed annually with leprosy-related G2D in this period [5]. In the last decades, Brazil has adopted extensive public health measures to improve the assessment and prevention of leprosy-related physical disabilities [6]. Nevertheless, a systematic review conducted by Vieira et al. (2018) [7], indicates that the proportion of leprosy cases presenting disability among children < 15 years remains high in Brazil, reflecting active transmission and challenges for case detection.

Although there have been large-scale studies in Brazil studying the social determinants of leprosy incidence and treatment default $[8,9]$, risk factors for leprosyassociated disability at the time of diagnosis remain scarcely investigated. In Brazil, there are problems related to underdiagnosis and underreporting of new cases of leprosy, which have had a major impact on the ability to plan control activities for the disease. In addition, primary health services face difficulties in monitoring patients after completing treatment and monitoring disabilities. Using nationwide linked data from the 100 Million Brazilian Cohort, this study used large-scale data to identify risk factors for having leprosy-related physical disabilities at the time of diagnosis.

\section{Methods \\ Study design and data source}

The 100 Million Brazilian Cohort $[10,11]$ was built by linking health and administrative records of individuals registered in the Cadastro Único para Programas Sociais (CadÚnico), a national registry for social assistance programs in the country. This database was created at the Centro de Integração de Dados e Conhecimentos para Saúde at Oswaldo Cruz Foundation (Cidacs, Salvador, Bahia, Brazil) and is part of the Center's mission to evaluate the impact of social determinants and policies on health. The cohort includes administrative records from over 114 million individuals who applied for social assistance between 2001 and 2015 .

As previously described $[8,9,12,13]$ the data from the 100 Million Brazilian Cohort was then linked to leprosy notification records in the national notifiable disease system, Sistema de Informação de Agravos de Notificação, SINAN-leprosy.

\section{Settings and participants}

The study population for this investigation included members of the 100 Million Brazilian Cohort followed from January 1st 2007 until December 31st 2014. Cohort members were excluded if they: (i) were diagnosed with leprosy prior to registration in CadÚnico, (ii) belonged to family units with no member aged over 15 years (i.e., children registered separately from their families), (iii) had less than 1 day of follow-up, (iv) were relapsed leprosy cases or (v) did not have information on grade of disability at diagnosis.

\section{Outcome and exposures}

For this study, the primary outcome was the detection of physical disabilities caused by leprosy, classified as grade 0 (G0D), grade 1 (G1D) or grade $2(\mathrm{G} 2 \mathrm{D})$. 
Exposure variables were related to individual socioeconomic indicators (i.e., sex, age, self-identified race/ethnicity, literacy, schooling, and employment status) and household living conditions (i.e., household density, housing materials, water source, electricity source, sewage disposal, and waste disposal). For individuals under 18 years old, education and employment were reported as the education level and employment status of the head of the family (here defined as the oldest member of the family).

Geographic exposures included Brazilian region of residence, urbanicity (urban or rural), and residence in a 'high-burden cluster'. The definition of clusters of higher incidence was the one used by Penna et al. (2009) [14], based on epidemiological data of Brazil from 1980 until 2007. These clusters were defined as 29 spatial clusters comprising 789 municipalities and were devised to facilitate decision-making for leprosy control across the country. Although these were defined more than 10 years ago, a recent study [15] analyzed the spatial distribution of leprosy in selected endemic regions of the country comparing the periods 2001-2003 versus 2010-2012 and concluded that there is significant overlap of clusters comparing both time periods.

Clinical exposures included the operational classification of leprosy (i.e., paucibacillary or multibacillary $[\mathrm{PB}$ or $\mathrm{MB}]$ ) and the number of skin lesions.

\section{Statistical analysis}

Descriptive analysis was performed to assess the distribution of the independent variables, followed by bivariate analysis with the outcome (presence of any degree of disability) to assess the strength of association between independent variables and grade of disability at diagnosis. Those with a $p$-value less than 0.1 were considered eligible for the multivariate model.

For the multivariate analysis, a multinomial logistic regression model with cluster-robust standard errors (i.e., accounting for familial clustering of covariates) to estimate the adjusted odds ratios (OR) was used, with grade zero disability cases used as the reference category. The adjusted ORs will therefore represent the odds of the outcome (G1D or G2D versus grade zero) associated with that particular category of the independent variable compared to the reference category for the same variable.

All analyses were performed using Stata, version 15.0 (Stata Corp LLC, College Station, Texas, USA).

\section{Ethics}

This study was performed under the international (Helsinki), Brazilian and United Kingdom research regulations and was approved by three Ethics Committees of Research: (i) University of Brasília (1.822.125), (ii)
Instituto Gonçalo Muniz - Fiocruz (1.612.302) and (iii) London School of Hygiene and Tropical Medicine's Research Committee (10580-1).

\section{Role of funding source}

This study was funded by The Medical Research Council (MR/N017250/1), Conselho Nacional das Fundações Estaduais de Amparo à Pesquisa / Economic and Social Research Council / Medical Research Council / Biotechnology and Biological Sciences Research Council / Conselho Nacional de Desenvolvimento Científico e Tecnológico / Fundação de Apoio à Pesquisa do Distrito Federal (CONFAP/ESRC/MRC/BBSRC/CNPq/FAPDF) - Doenças Negligenciadas, (Number 193.000.008/2016), and the Wellcome Trust $(202.912 / \mathrm{B} / 16 / \mathrm{Z})$. The funders of the study had no role in the design, data collection, analysis, interpretation, or writing the article.

\section{Results}

The study population included 21,565 new leprosy cases detected in Brazil between 2007 to 2014 (Fig. 1). At the time of diagnosis, 15,095 (63.1\%) cases had G0D, while grades 1 and 2 represented 21\% (5026) and 6\% (1444), respectively. In the multivariate model, 16,376 cases were included, as missing values for some variables prevented a number of cases from being included.

Newly detected leprosy cases had a mean age of 37.6 years old (SD 19.5), varying by the grade of disability (G0D 34.9; G1D 43.4; G2D 45.7) (Table 1). Overall, $49.6 \%$ of the leprosy cases were female, $72.1 \%$ was identified as mixed race ("pardo"), 79.3\% were literate and $60.7 \%$ had up to 5 years of education, and $50.9 \%$ were unemployed or unemployed but currently studying. Although $81.8 \%$ earned up to 0.5 minimum wage, $11.3 \%$ reported no source of income. Most of the leprosy cases lived in urban areas (79.5\%) and in the Northeast (40.4\%) and the North (23.6\%) regions. The greater proportion of the cases lived in municipalities that belonged to the epidemiologically-defined high incidence clusters (63.8\%). Also, $69.3 \%$ of the cases lived in brick or cement-made dwellings, with publicly provided water, garbage collection and electricity. However, $67 \%$ of them reported using a homemade tank as a sewage disposal system. There were more MB cases than PB (59.2\% vs $40.8 \%$ ) at time of diagnosis (Table 1).

In multivariate analysis, the odds of G1D were higher among leprosy cases aged over 15 years (OR 2.39; 95\%CI 2.06-2.77), as well as among those with lower levels of education - no education/pre-school (OR 1.64; 95\% CI $1.40-1.93$ ), $1-5$ years of education (OR 1.48; $95 \% \mathrm{CI}$ $1.28-1.70$ ), and $6-9$ years of education (OR $1.28 ; 95 \% \mathrm{CI}$ 1.10-1.48), unemployed (OR 1.19; 95\%CI 1.06-1.32) and living in rural areas (OR 1.14; 95\%CI 1.04-1.26) (Table 2). Cases with MB leprosy (OR 3.50; 95\%CI 3.13- 


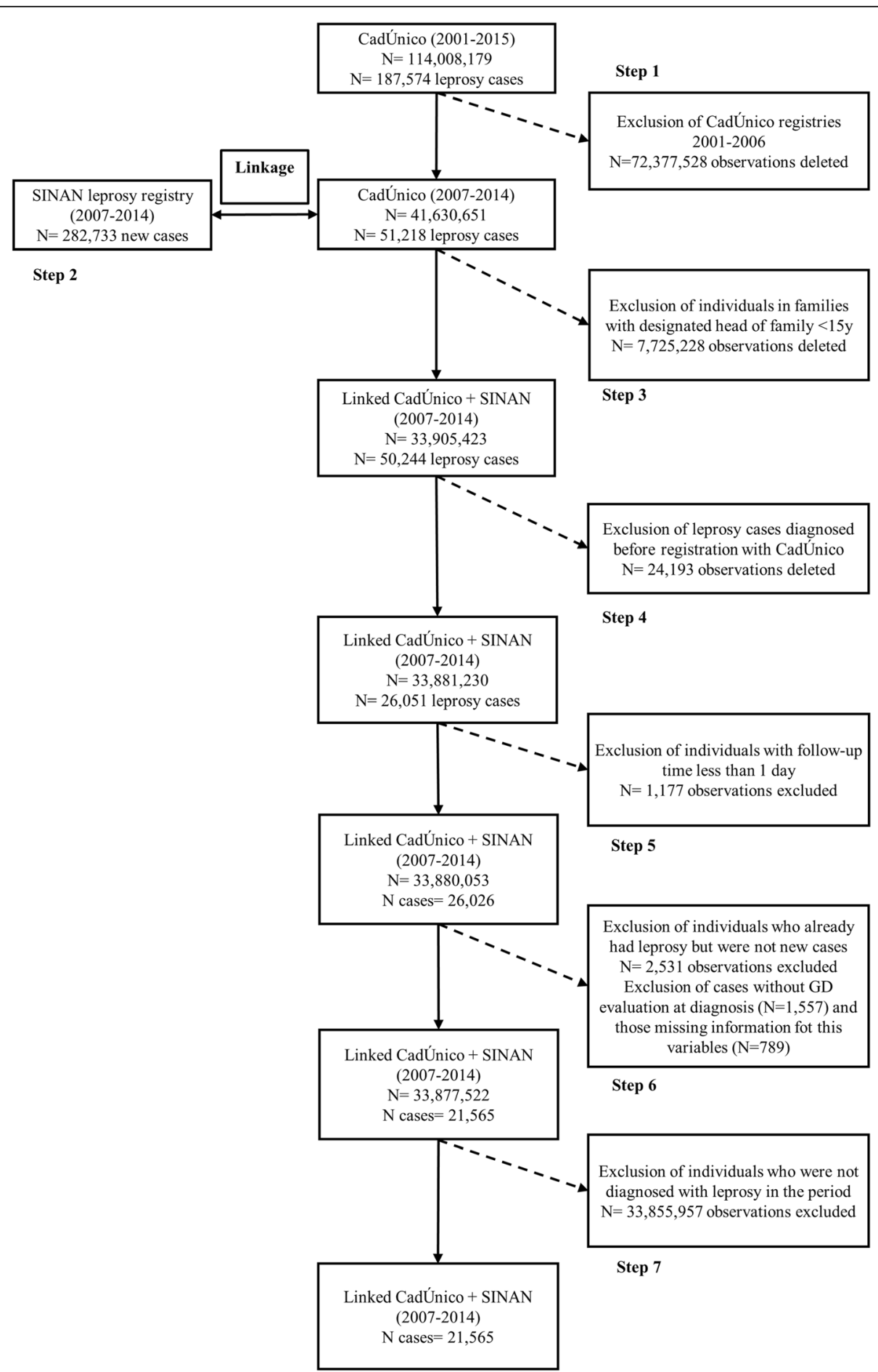

Fig. 1 Study population selection flowchart from the 100 Million Brazilian Cohort

3.92) and with lesions (OR 1.12; 95\%CI 1.02-1.24) were also more likely to have G1D. Factors that showed to be protective against G1D included being female (OR 0.81; 95\%CI 0.75-0.88), increased household density (>1 inhab/romm - OR 0.79; 95\%CI 0.71-0.88) and living in a high-incidence cluster municipality (OR 0.85; 95\%CI 0.78-0.93) (Table 2).

For G2D, the model showed similar risk factors to the G1D analysis (Table 2). Both age above 15 years old (OR 1.95 ; $95 \%$ CI $1.51-2.50)$ and lower levels of education 
Table 1 Characteristics of leprosy cases evaluated for physical disabilities. The 100 Million Brazilian Cohort, 2007-2014

\begin{tabular}{|c|c|c|c|c|}
\hline \multirow[t]{4}{*}{ Variables } & \multicolumn{3}{|c|}{ Physical Disabilities } & \multirow{4}{*}{$\begin{array}{l}\text { Total } \\
\mathrm{n}(\%)\end{array}$} \\
\hline & Grade 0 & Grade 1 & Grade 2 & \\
\hline & $(\mathrm{N}=15,095)$ & $(\mathrm{N}=5,026)$ & $(\mathrm{N}=1,444)$ & \\
\hline & $n(\%)$ & $n(\%)$ & $n(\%)$ & \\
\hline \multicolumn{5}{|l|}{ Individual characteristics } \\
\hline Age (Mean [SD]) & $34.9(19.2)$ & $43.4(18.6)$ & $45.7(19.0)$ & $37.6(19.5)$ \\
\hline \multicolumn{5}{|l|}{ Sex } \\
\hline Male & $6,984(46.3)$ & $2,915(58.0)$ & $965(66.8)$ & $10,864(50.4)$ \\
\hline Female & $8,111(53.7)$ & $2,111(42.0)$ & 479 (33.2) & $10,701(49.6)$ \\
\hline \multicolumn{5}{|l|}{ Ethnicity } \\
\hline White & 2,645 (17.9) & $1,076(21.8)$ & $330(23.2)$ & $4,051(19.2)$ \\
\hline Black & $1,178(8.0)$ & $412(8.4)$ & $132(9.3)$ & $1,722(8.1)$ \\
\hline Asian & $49(0.3)$ & $19(0.4)$ & $1(0.1)$ & $69(0.3)$ \\
\hline Mixed (brown) & $10,879(73.5)$ & $3,406(69.0)$ & $956(67.3)$ & $15,241(72.1)$ \\
\hline Indigenous & $48(0.3)$ & $20(0.4)$ & $1(0.1)$ & $69(0.3)$ \\
\hline Ignored/Missing & & & & $455(0.02)^{a}$ \\
\hline \multicolumn{5}{|l|}{ Literacy } \\
\hline Yes & $12,182(81.5)$ & $3,714(74.6)$ & $1,028(71.6)$ & $16,924(79.3)$ \\
\hline No & $2,760(18.5)$ & $1,262(25.4)$ & $407(28.4)$ & $4,429(20.7)$ \\
\hline Ignored/Missing & & & & $234(0.01)^{\mathrm{a}}$ \\
\hline \multicolumn{5}{|l|}{ Schooling } \\
\hline No education/Pre-school & $2,266(17.0)$ & $1,060(23.3)$ & $362(26.8)$ & $3,688(19.2)$ \\
\hline Primary School ( $1-5$ years) & $5,346(40.1)$ & $2,034(44.6)$ & $595(44.1)$ & $7,975(41.5)$ \\
\hline High School (6-9 years) & $3,981(29.9)$ & $1,101(24.1)$ & $302(22.4)$ & $5,384(28.0)$ \\
\hline Senior High School (10-12 years) & $1,677(12.6)$ & $350(7.7)$ & $89(6.6)$ & $2,116(11.0)$ \\
\hline Higher Education ( $\geq 12$ years) & $48(0.4)$ & $14(0.3)$ & $2(0.2)$ & $64(0.3)$ \\
\hline Ignored/Missing & & & & $2,566(0.1)^{a}$ \\
\hline \multicolumn{5}{|l|}{ Work condition } \\
\hline Employed & $6,801(50.6)$ & $2,073(46.1)$ & $562(44.2)$ & $9,436(49.1)$ \\
\hline Unemployed & $3,211(23.9)$ & $1,309(29.1)$ & $421(33.1)$ & $4,941(25.7)$ \\
\hline Unemployed but currently studying & $3,434(25.5)$ & $1,112(24.8)$ & $288(22.7)$ & $4,834(25.2)$ \\
\hline Ignored/Missing & & & & $2,615(0.1)^{a}$ \\
\hline \multicolumn{5}{|l|}{ Per capita income } \\
\hline No income & $1,682(11.1)$ & $577(11.5)$ & $173(12.0)$ & $2,432(11.3)$ \\
\hline 0-0.25 minimum wage & $8,580(56.8)$ & $2,428(48.3)$ & $681(47.2)$ & $11,689(54.2)$ \\
\hline $0.25-0.5$ minimum wage & $2,440(16.2)$ & $835(16.6)$ & $241(16.7)$ & $3,516(16.3)$ \\
\hline $0.5-1$ minimum wage & $1,910(12.7)$ & $961(19.1)$ & $285(19.7)$ & $3,156(14.6)$ \\
\hline$>1$ minimum wage & $482(3.2)$ & $225(4.5)$ & $64(4.4)$ & $771(3.6)$ \\
\hline Ignored/Missing & & & & $1(0.0)^{\mathrm{a}}$ \\
\hline \multicolumn{5}{|l|}{ Household characteristics } \\
\hline \multicolumn{5}{|l|}{ Region of residence } \\
\hline North & $3,636(24.1)$ & $1,164(23.2)$ & $298(20.6)$ & $5,098(23.6)$ \\
\hline Northeast & $6,401(42.4)$ & $1,822(36.2)$ & $497(34.4)$ & $8,720(40.4)$ \\
\hline Southeast & $1,966(13.2)$ & $814(16.2)$ & $297(20.6)$ & $3,107(14.4)$ \\
\hline South & $346(2.3)$ & $202(4.0)$ & $88(6.1)$ & $636(3.0)$ \\
\hline
\end{tabular}


Table 1 Characteristics of leprosy cases evaluated for physical disabilities. The 100 Million Brazilian Cohort, $2007-2014$ (Continued)

\begin{tabular}{|c|c|c|c|c|}
\hline \multirow[t]{4}{*}{ Variables } & \multicolumn{3}{|c|}{ Physical Disabilities } & \multirow{4}{*}{$\begin{array}{l}\text { Total } \\
\mathrm{n}(\%)\end{array}$} \\
\hline & Grade 0 & Grade 1 & Grade 2 & \\
\hline & $(\mathrm{N}=15,095)$ & $(\mathrm{N}=5,026)$ & $(\mathrm{N}=1,444)$ & \\
\hline & $n(\%)$ & $\mathrm{n}(\%)$ & $n(\%)$ & \\
\hline Midwest & $2,716(18.0)$ & $1,024(20.4)$ & $264(18.3)$ & $4,004(18.6)$ \\
\hline \multicolumn{5}{|l|}{ Area of residence } \\
\hline Urban & $12,100(80.2)$ & 3,894 (77.6) & $1,128(78.3)$ & $17,122(79.5)$ \\
\hline Rural & 2,984 (19.8) & $1,125(22.4)$ & $312(21.7)$ & $4,421(20.5)$ \\
\hline Ignored/Missing & & & & $22(0.0)^{\mathrm{a}}$ \\
\hline \multicolumn{5}{|l|}{ Household density } \\
\hline$\leq 0.5$ inhab/room & $5,014(33.7)$ & $2,141(43.2)$ & $619(43.7)$ & $7,774(36.6)$ \\
\hline 0.5-0.75 inhab/room & $2,802(18.8)$ & $848(17.1)$ & $230(16.2)$ & $3,880(18.2)$ \\
\hline 0.75-1.00 inhab/room & $3,320(22.3)$ & 970 (19.6) & $253(17.8)$ & $4,543(21.4)$ \\
\hline$>1.00 \mathrm{inhab} / \mathrm{room}$ & $3,754(25.2)$ & $995(20.1)$ & $316(22.3)$ & $5,065(23.8)$ \\
\hline Ignored/Missing & & & & $338(0.01)$ \\
\hline \multicolumn{5}{|l|}{ Construction material } \\
\hline Bricks/Cement & $10,429(70.0)$ & $3,347(67.5)$ & $975(68.7)$ & $14,751(69.3)$ \\
\hline Wood/Taipa/Others & $4,473(30.0)$ & $1,610(32.5)$ & $444(31.3)$ & $6,527(30.7)$ \\
\hline Ignored/Missing & & & & $318(0.01)^{a}$ \\
\hline \multicolumn{5}{|l|}{ Water supply } \\
\hline Public network (tap water) & $10,171(68.3)$ & $3,311(66.8)$ & $978(68.9)$ & $14,460(68.0)$ \\
\hline Well/Natural source/Others & $4,731(31.7)$ & $1,646(33.2)$ & $441(31.1)$ & $6,818(32.0)$ \\
\hline Ignored/Missing & & & & $318(0.01)^{\mathrm{a}}$ \\
\hline \multicolumn{5}{|l|}{ Electricity } \\
\hline Electricity with counter & $13,566(91.0)$ & $4,468(90.1)$ & $1,278(90.1)$ & $19,312(90.8)$ \\
\hline Electricity without counter & $1,336(9.0)$ & $489(9.9)$ & $141(9.9)$ & $1,966(9.2)$ \\
\hline Ignored/Missing & & & & $318(0.01)^{\mathrm{a}}$ \\
\hline \multicolumn{5}{|l|}{ Waste disposal system } \\
\hline Public network/Septic tank & $4,823(32.8)$ & $1,588(32.6)$ & $506(36.5)$ & $6,917(33.0)$ \\
\hline Homemade tank/Ditch/Others & $9,864(67.2)$ & $3,285(67.4)$ & $879(63.5)$ & $14,028(67.0)$ \\
\hline Ignored/Missing & & & & $705(0.03)^{a}$ \\
\hline \multicolumn{5}{|l|}{ Garbage disposal } \\
\hline Public collection system & $11,409(76.6)$ & $3,654(73.7)$ & $1,070(75.4)$ & $16,133(75.8)$ \\
\hline Burned/Buried/Outdoor disposal/Others & $3,494(23.4)$ & $1,303(26.3)$ & $349(24.6)$ & $5,146(24.2)$ \\
\hline Ignored/Missing & & & & $317(0.01)^{a}$ \\
\hline \multicolumn{5}{|l|}{ High-burden cluster municipality } \\
\hline No & $5,148(34.1)$ & $1,987(39.5)$ & $679(47.0)$ & $7,814(36.2)$ \\
\hline Yes & $9,947(65.9)$ & $3,039(60.5)$ & $765(53.0)$ & $13,751(63.8)$ \\
\hline \multicolumn{5}{|l|}{ Clinical characteristics } \\
\hline \multicolumn{5}{|l|}{ WHO operational classification } \\
\hline Paucibacillary & $7,698(51.0)$ & $968(19.3)$ & $128(8.9)$ & $8,794(40.8)$ \\
\hline Multibacillary & $7,396(49.0)$ & $4,058(80.7)$ & $1,316(91.1)$ & $12,770(59.2)$ \\
\hline Ignored/Missing & & & & $3(0.0)^{\mathrm{a}}$ \\
\hline \multicolumn{5}{|l|}{ Presence of lesions } \\
\hline No & $9,123(60.4)$ & $1,862(37.0)$ & $432(29.9)$ & $12,419(51.9)$ \\
\hline
\end{tabular}


Table 1 Characteristics of leprosy cases evaluated for physical disabilities. The 100 Million Brazilian Cohort, 2007-2014 (Continued)

\begin{tabular}{|c|c|c|c|c|}
\hline \multirow[t]{4}{*}{ Variables } & \multicolumn{3}{|c|}{ Physical Disabilities } & \multirow[t]{3}{*}{ Total } \\
\hline & Grade 0 & Grade 1 & Grade 2 & \\
\hline & $(\mathrm{N}=15,095)$ & $(\mathrm{N}=5,026)$ & $(\mathrm{N}=1,444)$ & \\
\hline & $n(\%)$ & $\mathrm{n}(\%)$ & $n(\%)$ & $n(\%)$ \\
\hline Yes & $5,940(39.4)$ & $3,135(62.4)$ & $1,004(69.5)$ & $11,419(47.8)$ \\
\hline Ignored/Missing & $32(0.2)$ & $29(0.6)$ & $8(0.6)$ & $73(0.3)^{a}$ \\
\hline
\end{tabular}

${ }^{a}$ The percentage of ignored/missing data refers a part of the total

appeared to influence the odds of had G2D, specifically, no education/pre school (OR 1.91; 95\%CI 1.44-2.53) and $1-5$ years of education (OR 1.64; $95 \% \mathrm{CI} 1.27-2.12$ ). Being a MB leprosy case was also a risk factor (OR 8.22; 95\%CI 6.51-10.38) to have G2D. However, being female (OR $0.61 ; 95 \%$ CI $0.53-0.70$ ) and living in a highincidence cluster municipality (OR 0.67 ; 95\%CI $0.58-$ 0.78 ) decreased the odds of presenting G2D at diagnosis. Protective effects were also observed for living in the North (OR 0.53; 95\%CI 0.39-0.72), Northeast (OR 0.53; 95\%CI 0.39-0.71) and Midwest regions (OR 0.50; 95\%CI 0.36-0.68) (Table 2).

\section{Discussion}

This study investigated factors associated with leprosyrelated disability in a large Brazilian patient population of 21,565 new leprosy cases. Our results showed lower odds of having grade 1 or grade 2 physical disabilities associated with being a woman, living in the North, Northeast and Midwest regions or in high-incidence clusters, in urban areas, and increased household crowding. However, new leprosy cases aged over 15 years, with a lower levels of education, unemployed and with multibacillary leprosy had higher chances of presenting grade 1 or grade 2 physical disabilities at diagnosis.

The higher likelihood of leprosy-related disabilities found among those older than 15 years is similar to previous studies. In a hyperendemic area of the Midwest region of Brazil, the estimated risk ratio of G2D was 5.3 times higher among patients aged $\geq 45$ years [16]. In the state of Minas Gerais, a retrospective study showed that age above 15 years was an important risk factor for the development of physical disability in leprosy patients as well [17]. A study of patients from the state of Maranhão showed a progressive increase in the chances of developing physical disability among those older than 15 years, ranging from 3 to 10.4 times higher risk [18]. Considering that the duration of the disease is directly related to age and, given the chronic nature of the disease, increasing age may result in more advanced disabilities $[17,19]$.

Regarding gender, some studies did not identify an association between gender and level of disability [20-22]. However, other studies reported higher grades of physical disability among male individuals with leprosy [17,
23]. Men are generally more exposed to $M$. leprae and have reduced contact with health care, which may delay diagnosis and increases the risk of developing physical disabilities [24]. For the general population in Brazil, between 2012 and 2016, the detection rate of new cases with physical disability grade 2 was higher in males. This rate was 15.2 and 6.1 cases per 1 million among men and women, respectively [5]. Cultural factors may explain the difference by gender as women may be more likely to seek health care [18].

Our study also suggests that higher levels of education were negatively associated with the presence of physical disabilities at diagnosis, which is consistent with the literature $[16,17]$. Higher education has been shown to be associated with better understanding of the disease and, consequently, better access and utilization of health services. Regular treatment and evaluation, as well as selfcare, are aspects that may prevent the worsening of clinical manifestations $[17,25]$.

The fact that cases from the Northeast and the North regions were less likely to present G2D contrasts with the findings from Freitas and colleagues (2014) [26], which showed greater proportions of G2D in municipalities with higher incidence rates of leprosy. In their work, the explanation presented for this fact was that better surveillance was leading to a higher detection rate. And subsequently, this was leading to more G2D cases that were found by contact tracing. However, the areas with higher endemicity, in general, do not have a better structured surveillance and care system, as they are systematically poorer. The clusters are located in more vulnerable areas.

Therefore, this fact is likely due to a more sensitive health staff and surveillance system to case detection, therefore more capable of detecting leprosy cases earlier. Assuming that disability is a marker for late diagnosis, it is expected that regions of high endemicity will show a lower chance of patients presenting with grades 1 and 2 disability. G2D, as already mentioned, may indicate late diagnosis and a suboptimal surveillance system. According to Penna et al. (2009) [14], access to primary health care units has improved mainly in rural areas and small towns, improving the diagnosis of leprosy in the first decade of this century. Also, as her work emphasizes, 
Table 2 Univariate and adjusted analyses for grade of physical disabilities. The 100 Million Brazilian Cohort, 2007-2014

\begin{tabular}{|c|c|c|c|c|}
\hline & \multicolumn{2}{|l|}{ Grade 1} & \multicolumn{2}{|l|}{ Grade 2} \\
\hline & $\begin{array}{l}\text { OR }_{\text {crude }}{ }^{a} \\
(95 \% \mathrm{Cl})\end{array}$ & $\begin{array}{l}\mathrm{OR}_{\mathrm{adj}}^{\mathrm{b}, \mathrm{c}} \\
(95 \% \mathrm{Cl})\end{array}$ & $\begin{array}{l}\text { OR }_{\text {crude }}{ }^{a} \\
(95 \% \mathrm{Cl})\end{array}$ & $\begin{array}{l}\mathrm{OR}_{\mathrm{adj}}^{\mathrm{b}, \mathrm{c}} \\
(95 \% \mathrm{Cl})\end{array}$ \\
\hline & $(N=5,026)$ & $(\mathrm{N}=5,026)$ & $(\mathrm{N}=1,444)$ & $(\mathrm{N}=1,444)$ \\
\hline \multicolumn{5}{|l|}{ Individual characteristics } \\
\hline \multicolumn{5}{|l|}{ Age } \\
\hline Up to 15 years old & 1.00 & 1.00 & 1.00 & 1.00 \\
\hline$>15$ years old & $3.41(3.01-3.87)$ & $2.39(2.06-2.77)$ & $3.28(2.63-4.11)$ & $1.95(1.51-2.50)$ \\
\hline \multicolumn{5}{|l|}{ Sex } \\
\hline Male & 1.00 & 1.00 & 1.00 & 1.00 \\
\hline Female & $0.62(0.58-0.66)$ & $0.81(0.75-0.88)$ & $0.48(0.38-0.48)$ & $0.61(0.53-0.70)$ \\
\hline \multicolumn{5}{|l|}{ Schooling } \\
\hline No education/Pre-school & $1.60(0.86-2.94)$ & $1.64(1.40-1.93)$ & $3.83(0.93-15.88)$ & $1.91(1.44-2.53)$ \\
\hline Primary School ( $1-5$ years) & $1.30(0.71-2.38)$ & $1.48(1.28-1.70)$ & $2.67(0.65-11.04)$ & $1.64(1.27-2.12)$ \\
\hline High School (6-9 years) & $0.95(0.52-1.74)$ & $1.28(1.10-1.48)$ & $1.82(0.44-7.55)$ & $1.31(1.00-1.72)$ \\
\hline Senior High School (10-12 years) & $0.72(0.39-1.32)$ & - & $1.27(0.30-5.34)$ & - \\
\hline Higher Education ( $\geq 12$ years) & 1.00 & 1.00 & 1.00 & 1.00 \\
\hline \multicolumn{5}{|l|}{ Work condition } \\
\hline Employed & 1.00 & 1.00 & 1.00 & 1.00 \\
\hline Unemployed & $1.06(0.98-1.16)$ & $1.19(1.06-1.32)$ & $1.01(0.86-1.18)$ & $1.47(1.23-1.74)$ \\
\hline Unemployed but currently studying & $1.34(1.23-1.45)$ & $1.13(1.03-1.24)$ & $1.59(1.39-1.81)$ & $1.15(0.98-1.35)$ \\
\hline \multicolumn{5}{|l|}{ Household characteristics } \\
\hline \multicolumn{5}{|l|}{ Region of residence } \\
\hline North & $0.55(0.46-0.66)$ & $0.91(0.72-1.15)$ & $0.32(0.25-0.42)$ & $0.53(0.39-0.72)$ \\
\hline Northeast & $0.49(0.41-0.58)$ & $0.81(0.64-1.01)$ & $0.31(0.24-0.39)$ & $0.53(0.39-0.71)$ \\
\hline Southeast & $0.70(0.58-0.85)$ & $1.06(0.84-1.33)$ & $0.58(0.45-0.76)$ & $0.80(0.59-1.08)$ \\
\hline South & 1.00 & 1.00 & 1.00 & 1.00 \\
\hline Midwest & $0.65(0.54-0.78)$ & $0.86(0.68-1.09)$ & $0.38(0.29-0.49)$ & $0.50(0.36-0.68)$ \\
\hline \multicolumn{5}{|l|}{ Area of residence } \\
\hline Urban & 1.00 & 1.00 & 1.00 & 1.00 \\
\hline Rural & $1.17(1.08-1.27)$ & $1.14(1.04-1.26)$ & $1.12(0.98-1.28)$ & $1.05(0.89-1.24)$ \\
\hline \multicolumn{5}{|l|}{ Household density } \\
\hline$\leq 0.5$ inhab/room & 1.00 & 1.00 & 1.00 & 1.00 \\
\hline 0.5-0.75 inhab/room & $0.71(0.65-0.78)$ & $0.87(0.78-0.98)$ & $0.66(0.57-0.78)$ & $0.96(0.80-1.16)$ \\
\hline 0.75-1.00 inhab/room & $0.68(0.63-0.75)$ & $0.87(0.78-0.97)$ & $0.62(0.53-072)$ & $0.85(0.71-1.03)$ \\
\hline > 1.00 inhab/room & $0.62(0.57-0.68)$ & $0.79(0.71-0.88)$ & $0.68(0.59-0.79)$ & $1.04(0.87-1.23)$ \\
\hline \multicolumn{5}{|l|}{ High-burden cluster municipality } \\
\hline No & 1.00 & 1.00 & 1.00 & 1.00 \\
\hline Yes & $0.79(0.74-0.85)$ & $0.85(0.78-0.93)$ & $0.58(0.52-0.65)$ & $0.67(0.58-0.78)$ \\
\hline \multicolumn{5}{|l|}{ Clinical characteristics } \\
\hline \multicolumn{5}{|l|}{ WHO operational classification } \\
\hline Paucibacillary & 1.00 & 1.00 & 1.00 & 1.00 \\
\hline Multibacillary & $4.36(4.04-4.71)$ & $3.50(3.13-3.92)$ & $10.70(8.90-12.87)$ & $8.22(6.51-10.38)$ \\
\hline
\end{tabular}


Table 2 Univariate and adjusted analyses for grade of physical disabilities. The 100 Million Brazilian Cohort, $2007-2014$ (Continued)

\begin{tabular}{|c|c|c|c|c|}
\hline & \multicolumn{2}{|l|}{ Grade 1} & \multicolumn{2}{|l|}{ Grade 2} \\
\hline & $\begin{array}{l}\text { OR }_{\text {crude }}{ }^{a} \\
(95 \% \mathrm{Cl})\end{array}$ & $\begin{array}{l}\mathrm{OR}_{\text {adj }}^{\mathrm{b}, \mathrm{c}} \\
(95 \% \mathrm{Cl})\end{array}$ & $\begin{array}{l}\text { OR }_{\text {crude }}{ }^{a} \\
(95 \% \mathrm{Cl})\end{array}$ & $\begin{array}{l}\mathrm{OR}_{\mathrm{adj}}^{\mathrm{b}, \mathrm{c}} \\
(95 \% \mathrm{Cl})\end{array}$ \\
\hline & $(N=5,026)$ & $(\mathrm{N}=5,026)$ & $(\mathrm{N}=1,444)$ & $(\mathrm{N}=1,444)$ \\
\hline \multicolumn{5}{|c|}{ Presence of lesions } \\
\hline No & 1.00 & 1.00 & 1.00 & 1.00 \\
\hline Yes & $2.56(2.38-2.76)$ & $1.12(1.02-1.24)$ & $3.44(3.15-3.93)$ & $1.03(0.88-1.20)$ \\
\hline
\end{tabular}

there is a cultural component related to the presence of skin lesions in populations that are used to seeing this type of clinical manifestation of the disease (i.e., in highly endemic areas), coupled with health-seeking behavior among these individuals.

The study by Freitas et al. (2014) [26] looked at risk factors and identified a high new case detection rate in the Midwest and North regions compared to the South, large cities and greater urbanization, median and high illiteracy rate, income inequality (Gini index), hosehold' crowding, worse sanitation condition, and percentage of cases with grade 2 disability. Differences between these findings and our results may stem from the fact that our study focused on G2D at diagnosis, which does not necessarily mirror risk factors for higher incidence or new case detection rate. As we are hypothesizing, high incidence and detection of disabilities may be influenced by different factors. It is technically difficult to separate short- and long-term effects of increased surveillance [8].

The association between the proportion of multibacillary leprosy and presentation of G2D has been shown in the past $[16,27,28]$. Studies conducted in some Brazilian municipalities indicate that at the time of diagnosis, educational level and operational classification are statistically associated with the development of physical disabilities. It is emphasized that multibacillary patients are twice more likely to develop sequelae than paucibacillary patients [29].

Our study has several strengths. Although there are studies addressing leprosy related disabilities, (i) our large sample size and extensive follow up period allowed us to evaluate determinants of leprosy-related physical disabilities to an extent that is rarely possible; (ii) this study linked data from over 100 million individuals and was able to assess factors associated with physical disability in an unprecedented way; (iii) additionally, using administrative databases linkage we also were able to evaluate a wider range of variables available in CadÚnico and; (iv) unlike other studies, we analyzed the most vulnerable fraction of the Brazilian population, for whom biological and povertyrelated risk factors for leprosy overlap.
Nevertheless, our study has some limitations. The use of secondary data originated from routine surveillance activities always brings the issue of completeness of information. We did not have complete information on disability evaluation at diagnosis $(n=1557)$ and at discharge. The latter was poorly collected to an extent that did not allow us to use that timepoint in the analysis. Efforts should be undertaken to stress the importance of performing this evaluation at discharge and record it in the information systems. Other factors associated with disability were not available in our database and therefore, could not be assessed, such as health services characteristics and patients' perception and knowledge about leprosy. In addition, although there is biological plausibility and references showing the association between leprosy reactions and presentation of disability [25, 27], this information was not obtained in our study population at time of diagnosis. Reactions are reported in the system only when the episode happens during the course of treatment, and this precludes us from assessing this topic in our study.

\section{Conclusion}

The findings suggest that the development of leprosyrelated physical disabilities remains a public health problem, mainly for those with severe clinical features and worse socioeconomic conditions. Early diagnosis is paramount to decrease the incidence of disabilities and focus should be given to younger patients, considering these individuals are of working age. Our study points to the need for strengthening control actions in non-endemic areas in Brazil, where cases may be missed when presented at early stages in the course of infection. Besides, social protection policies and initiatives are key to lead us to effective leprosy control - evidence that has been put forth a century ago [30] and yet remains valid. Future research should study disability-related socioeconomic and clinical factors at the end of treatment and explore if the findings from this work will hold among relapses or reinfections.

\section{Abbreviations}

95\% Cl: Confidence Interval of 95\%; BBSRC: Biotechnology and Biological Sciences Research Council; Cadúnico: Cadastro Único para Programas Sociais; 
Cidacs: Centro de Integração de Dados e Conhecimentos para Saúde; CNPq: Conselho Nacional de Desenvolvimento Científico e Tecnológico; CONFAP: Conselho Nacional das Fundações Estaduais de Amparo à Pesquisa; ESRC: Economic and Social Research Council; FAPDF: Fundação de Apoio à Pesquisa do Distrito Federal; G0D: Grade 0 disability; G1D: Grade 1 disability; G2D: Grade 2 disability; M. leprae: Mycobacterium leprae; MB: Multibacillary; MRC: Medical Research Council; OR: Odds Ratio; PB: Paucibacillary; SINA $\mathrm{N}$ : Sistema de Informação de Agravos de Notificação; WHO: World Health Organization

\section{Acknowledgements}

Not Applicable.

\section{Authors' contributions}

MNS participated in the study conceptualization, investigation, formal analysis and visualization, writing of the original draft, interpretation of the results and revision and editing of the final version of the manuscript. JSN participated in the study conceptualization, investigation, formal analysis and visualization, writing of the original draft, interpretation of the results and revision and editing of the final version of the manuscript. She also participated in the supervision and funding acquisition. JMP participated in the investigation, formal analysis and visualization, interpretation of the results and revision and editing of the final version of the manuscript. AAM participated in the investigation, formal analysis and visualization, interpretation of results and revision and editing of the final version of the manuscript. MYl participated in the investigation, interpretation of results and revision and editing of the final version of the manuscript. CSST participated in formal analysis and visualization, interpretation of the results and revision and editing of the final version of the manuscript. MLFP participated in the interpretation of the results and revision and editing of the final version of the manuscript. She also participated in the supervision and funding acquisition. LS participated in the interpretation of the results and revision and editing of the final version of the manuscript. LCR participated in the study conceptualization, interpretation of the results and revision and editing of the final version of the manuscript. She also participated in the supervision and funding acquisition. MLB participated in the study conceptualization, interpretation of the results and revision and editing of the final version of the manuscript. He also participated in the supervision and funding acquisition. EBB participated in the study conceptualization, investigation, formal analysis and visualization, interpretation of the results and revision and editing of the final version of the manuscript. GOP participated in the study conceptualization, interpretation of the results and revision and editing of the final version of the manuscript. He also participated in the supervision and funding acquisition. All authors read and approved the final manuscript.

\section{Funding}

This study was funded by the Medical Research Council (MRC) (MR/N017250/ 1), CONFAP/ESRC/MRC/BBSRC/CNPq/FAPDF 2015 - Neglected Tropical Diseases (FAP-DF 193.000.008/2016) to G.O.P and the Wellcome Trust (Grant 202912/Z/16/Z). The funders had no role in the design, data collection, analysis, interpretation, or writing of this article.

\section{Availability of data and materials}

The data that support the findings of this study are available from Center of Data and Knowledge Integration for Health (Cidacs - https://cidacs.bahia. fiocruz.br/) but restrictions apply to the availability of these data, which were used under license for the current study, and so are not publicly available. Data are however available from the authors upon reasonable request and with permission of Cidacs.

\section{Ethics approval and consent to participate}

This study was performed under the international (Helsinki), Brazilian and UK research regulations and was approved by the Three Ethics Committee of Research: (i) University of Brasília (1.822.125), (ii) Instituto Gonçalo Muniz Fiocruz (1.612.302) and (iii) London School of Hygiene and Tropical Medicine's Research Committee (10580-1). We declare that the data used in this study we extracted from a de-identified dataset before its use. For this investigation, the Ministry of Health and the Ministry of Social Development formally shared raw data to CIDACS in order to perform data linkage, which in turn allowed this study to be carried out. Both Ministries have strict requirements to provide Centers with identified data for linkage, which were fulfilled by CIDACS. Researchers, nevertheless, receive de-identified data to work with, preserving anonimity of patients.

\section{Consent for publication}

Not applicable.

\section{Competing interests}

The authors declare that they have no competing interests.

\section{Author details}

${ }^{1}$ Núcleo de Medicina Tropical, Universidade de Brasília, Avenida L3 Norte, s/ $\mathrm{n}^{\circ}$, Campus Universitário Darcy Ribeiro, Gleba A, Brasília, Distrito Federal CEP 70297-400, Brazil. ${ }^{2}$ Centro de Integração de Dados e Conhecimentos para Saúde (Cidacs), Fundação Oswaldo Cruz, Rua Mundo, s/n Parque Tecnológico da Bahia - Trobogy, Salvador CEP 41745-715, Brazil. Instituto de Saúde Coletiva, Universidade Federal da Bahia, Rua Basílio da Gama, s/nº Canela, Salvador, Bahia CEP 40110-040, Brazil. ${ }^{4}$ Departamento de Estatística, Universidade Federal Bahia, Rua Barão de Jeremoabo, $s / n^{\circ}$ - Ondina, Salvador, Bahia CEP 40170-115, Brazil. ${ }^{5}$ Departamento de Epidemiologia e Bioestatística, Universidade Federal Fluminense, Bloco do Hospital Universitário Antônio Pedro (Huap) - $3^{\circ}$ andar, Rua Marquês do Paraná, 303, Centro, Niterói, Rio de Janeiro CEP 24030-210, Brazil. 'Department of Non-Communicable Disease Epidemiology, London School of Hygiene \& Tropical Medicine, Keppel Street, London WC1E 7HT, UK. ${ }^{7}$ Health Data Research (HDR), London, UK. ${ }^{8}$ Department of Infectious Disease Epidemiology, London School of Hygiene \& Tropical Medicine, Keppel Street, London WC1E 7HT, UK. ${ }^{9}$ Escola Fiocruz de Governo, Fiocruz Brasília. Avenida L3 Norte, s/nº, Campus Universitário Darcy Ribeiro, Gleba A, Brasília, Distrito Federal CEP 70904-130, Brazil.

Received: 22 May 2020 Accepted: 28 January 2021

Published online: 22 March 2021

\section{References}

1. Wilder-Smith EP, Van Brakel WH. Nerve damage in leprosy and its management. Nat Clin Pract Neurol. 2008:4(12):656-63.

2. Wilder-Smith A, Kurniasari I, Kusumawardhani L, Kasim M, Beise K, Yulihane $\mathrm{R}$, et al. Disability in people affected by leprosy: the role of impairment, activity, social participation, stigma and discrimination. Glob Health Action. 2012;5(1):18394.

3. Brasil. Ministério da Saúde. Secretaria de Vigilância em Saúde. Diretrizes para vigilância, atenção e eliminacao da hanseníase como problema de saúde pública: manual técnico-operacional. 2016. Available in: http://portalsaude. saude.gov.br/images/pdf/2016/fevereiro/04/diretrizes-eliminacaohanseniase-4fev16-web.pdf. Accessed 31 Mar 2020.

4. World Health Organization, Regional Office for South-East Asia. Global Leprosy Strategy 2016-2020: Accelerating towards a leprosy-free world. WHO Regional Office for South-East Asia: WHO; 2016. Available in: https:// apps.who.int/iris/handle/10665/208824.

5. Brasil. Ministério da Saúde. Boletim Epidemiológico. Caracterização da situação epidemiológica da hanseníase e diferenças por sexo, Brasil, 20122016. Ministério da Saúde. 2018;49:1-12. Available in: http://portalarquivos2. saude.gov.br/images/pdf/2018/janeiro/31/2018-004-Hanseniase-publicacao. pdf. Accessed 31 Mar 2020

6. Oliveira MLW, Grossi MAF, Oliveira CF, Sena NSA, Daxbacher E, Penna GO. Commitment to reducing disability: the Brazilian experience. Lepr Rev. 2010; 81(4):342-5

7. MCA V, Nery JS, Paixão ES, Freitas de Andrade KV, Oliveira Penna G, Teixeira MG. Leprosy in children under 15 years of age in Brazil: A systematic review of the literature. PLoS Negl Trop Dis. 2018;12(10):e0006788.

8. Nery JS, Ramond A, Pescarini JM, Alves A, Strina A, Ichihara MY, et al. Socioeconomic determinants of leprosy new case detection in the 100 million Brazilian cohort: a population-based linkage study. Lancet Glob Heal. 2019;7(9):e1226-36.

9. Andrade KVF, Nery JS, Pescarini JM, Ramond A, Souza Teles Santos CA, Ichihara MY, et al. Geographic and socioeconomic factors associated with leprosy treatment default: An analysis from the 100 Million Brazilian Cohort. PLoS Negl Trop Dis. 2019;13(9):e0007714. 
10. Cidacs. Centro de Integração de Dados e Conhecimento para a Saúde. The 100 Million Brazilian Cohort. 2019. Available in: https://cidacs.bahia.fiocruz. br/. Accessed 31 Mar 2020.

11. Barreto ML, Ichihara MY, Almeida BA, Barreto ME, Cabral L, Fiaccone RL, et al. The Centre for Data and Knowledge Integration for health (CIDACS): an experience of linking health and social data in Brazil. Int J Heal Soc Data Brazil. 2019;4(2):1-11.

12. Pescarini JM, Williamson E, Nery JS, Ramond A, Ichihara MY, Fiaccone RL, et al. Effect of a conditional cash transfer program on leprosy treatment adherence and cure among patients from the nationwide 100 million Brazilian cohort: a quasi-experimental study. Lancet Infect Dis. 2020;20(5):618-27.

13. Teixeira CSS, Pescarini JM, Alves FJO, Nery JS, Sanchez MN, Teles C, et al. Incidence of and factors associated with leprosy among household contacts of patients with leprosy in Brazil. JAMA Dermatology. 2020;156(6):640-8.

14. Penna MLF, Oliveira MLVDR, Penna GO. The epidemiological behaviour of leprosy in Brazil. Lepr Rev. 2009;80(3):332-44.

15. Freitas LRS, Duarte EC, Garcia LP. Trends of main indicators of leprosy in Brazilian municipalities with high risk of leprosy transmission, 2001-2012. BMC Infect Dis. 2016;16(1):1-10.

16. Monteiro LD, Martins-Melo FR ogerlândi., Brito AL im., Alencar CH enriqu., Heukelbach J. Physical disabilities at diagnosis of leprosy in a hyperendemic area of Brazil: trends and associated factors. Lepr Rev. 2015;86:240-50.

17. Moschioni C, Antunes CM de F, Grossi MAF, Lambertucci JR. Risk factors for physical disability at diagnosis of 19,283 new cases of leprosy. Rev Soc Bras Med Trop. 2010;43(1):19-22.

18. Araujo AER DAE, Maria Cardoso De Aquino D, IMB G, SRF P, Fiqueiredo IA, Serra HO, et al. Factors associated with neural alterations and physical disabilities in patients with leprosy in São Luis, state of Maranhão, Brazil. Rev Soc Bras Med Trop. 2014;47(4):490-7.

19. Monteiro LD, de Alencar CHM, Barbosa JC, Braga KP, de Castro MD, Heukelbach J. Incapacidades físicas em pessoas acometidas pela hanseníase no período pós-alta da poliquimioterapia em um município no Norte do Brasil. Cad Saude Publica. 2013;29(5):909-20.

20. Araújo AERA, de Aquino DMC, Goulart IMB, Pereira SRF, Figueiredo IA, Serra $\mathrm{HO}$, et al. Complicações neurais e incapacidades em hanseníase em capital do nordeste brasileiro com alta endemicidade. Rev Bras Epidemiol. 2014; 17(4):899-910.

21. Sharma U, Moore D, Sonawane S. Attitudes and concerns of pre-service teachers regarding inclusion of students with disabilities into regular schools in Pune, India. Asia-Pacific J Teach Educ. 2009;37(3):319-31.

22. Ribeiro $\mathrm{G}$ de C, Félix Lana FC. Incapacidades físicas em hanseníase: caracterização, fatores relacionados e evolução. Cogitare Enferm 2015;20(3):496-503.

23. Gonçalves SD, Sampaio RF, Antunes CM de F. Fatores preditivos de incapacidades em pacientes com hanseníase. Rev Saude Publica. 2009;43(2):267-74.

24. Nobre ML, Illarramendi X, Dupnik KM, Hacker M de A, Nery JA da C, Jerônimo SMB, et al. Multibacillary leprosy by population groups in Brazil: Lessons from an observational study. PLoS Negl Trop Dis. 2017;11(2):e0005364.

25. Raposo MT, Reis MC, Caminha AV de Q, Heukelbach J, Parker LA, PastorValero M, et al. Grade 2 disabilities in leprosy patients from Brazil: need for follow-up after completion of multidrug therapy. PLoS Negl Trop Dis. 2018; 12(7):1-12.

26. Freitas LRS, Duarte EC, Garcia LP. Leprosy in Brazil and its association with characteristics of municipalities: ecological study, 2009-2011. Trop Med Int Heal. 2014;19(10):1216-25.

27. Chukwu JN, Ekeke N, Nwafor CC, Meka AO, Alphonsus C, Mbah OK, et al. Worsening of the disability grade during leprosy treatment: prevalence and its determinants in southern Nigeria. Trans R Soc Trop Med Hyg. 2018; 112(11):492-9.

28. Withington SG, Joha S, Baird D, Brink M, Brink J. Assessing socio-economic factors in relation to stigmatization, impairment status, and selection for socio-economic rehabilitation: a 1-year cohort of new leprosy cases in North Bangladesh. Lepr Rev. 2003;74(2):120-32.

29. Santana EMF de, Brito KKG de, Antas EMV, Nogueira J de A, Leadebal ODCP, da Silva MA, et al. Factors associated with the development of physical disabilities in Hansen's disease Rev Inst Med Trop Sao Paulo 2018;60:1-7.

30. Lie HP. Why is leprosy decreasing in Norway? Trans R Soc Trop Med Hyg. 1929;22(4):357-66.

\section{Publisher's Note}

Springer Nature remains neutral with regard to jurisdictional claims in published maps and institutional affiliations.

\section{Ready to submit your research? Choose BMC and benefit from:}

- fast, convenient online submission

- thorough peer review by experienced researchers in your field

- rapid publication on acceptance

- support for research data, including large and complex data types

- gold Open Access which fosters wider collaboration and increased citations

- maximum visibility for your research: over $100 \mathrm{M}$ website views per year

At BMC, research is always in progress.

Learn more biomedcentral.com/submissions 